\title{
Recap of the 2014 Media Democracy Days
}

\section{Robert Hackett}

School of Communication

Simon Fraser University

The Media Democracy Day (MDD) project is an annual event for alternative, independent, and democratic media in Canada. It has approached the project of media reform with a three-pronged ambition: Know the Media, Be the Media, and Change the Media. This year, MDD's annual conference was held between Nov. $7^{\text {th }}$ and $8^{\text {th }}$ at Vancouver Public Library. For more information about MDD, Please visit http://mediademocracyproject.ca/.

The following message was written by Prof. Robert Hackett, co-founder of the Media Democracy Day project.

As a co-founder of Media Democracy Days in 2001, I would like to congratulate this year's team on an outstanding event. This was my 14th consecutive Media Democracy Day (I did miss the 2012 one, but participated from London via video), and this year's event could well have been the best produced, and certainly one of the most interesting and best attended one: nearly every session was full to capacity. For their indefatigable work since MDD 2013, particular kudos go to Stuart Poyntz; MDD staff Gil Aguilar, Mariele Guerrero, and Helena Krobath; our former colleague Kathleen Cross; and the many student volunteers. Thanks also to the School of Communication and the FCAT dean's office for their continuing support for this event.

Robert McChesney, possibly America's best-known media reform advocate, told us that he is extremely impressed by what we have built each year in Vancouver.

A woman at the Media Fair table for Vancouver Rape Relief \& Women's Shelter told me that a major reason for their being there was to connect with other activists and to find potential allies in other movements; Media Democracy Day is one of the best opportunities, maybe the best, to do that in Vancouver. Her comment reinforces what Bill Carroll and I wrote about ten years ago (when Media Democracy Day was smaller in scale), that media democratization is a nexus between movements, one that potentially strengthens them all. Media Democracy Day has been a springboard for helping to launch initiatives like thetyee.ca, and OpenMedia.ca. It's also an outstanding showcase for our School's engagement with the community.

Onwards!

Prof. Robert Hackett

School of Communication

Simon Fraser University 